\title{
SPATIAL TRANSFORMATION IN THE URBAN PERIPHERY - A STUDY OF LUBHU, LALITPUR
}

\author{
Rijina Bajracharya
}

\author{
Department of Architecture, Khwopa Engineering College, Libali-8, Bhaktapur, Nepal
}

\begin{abstract}
Cities are in a constant state of transformation. With the growing urbanization, spatial structures are developed or replaced by the new one with respect to time. The towns located at the urban periphery of such city centers have always been the foremost target space to cater the increasing urban growth. Thus the settlement pattern, spatial structures and cultural integrity of those towns are exposed to an inevitable process of transformation along with modernization. However, the issues of transformation may vary depending on the context. Thus the aim of the research (which is based on the household survey of 2010 A.D.) is to understand the spatial transformation and identify the issues in this transformation process in Lubhu, one of the traditional towns in Kathmandu Valley, located in the close proximity of urban boundary of Lalitpur. Since the town has two major aspects of spatial layout, the first being the traditional old settlement confined within the town gates at four cardinal directions and next the agricultural land beyond the traditional boundary, the research makes an attempt to analyze transformations namely an intensive (within the existing settlement) and an extensive (in peripheral agricultural land) transformation with some exemplary illustrations. The theoretical framework derived after the literature review facilitates the analysis of the spatial transformations happening in Lubhu.
\end{abstract}

Keywords: Transformation, spatial organization, spatial structures, non spatial structures, intensive and extensive transformation

\section{Introduction}

In Kathmandu Valley, the three major cities Kathmandu, Patan (Lalitpur) and Bhaktapur are urbanizing in a rapid pace. The expansion of these city cores is also influencing the other settlements which are close to its municipal boundaries and have easy road access. As discussed in KVTDC (2002), there is a lack of policy to have clear cut delineation of urban rural boundary, and there is no strategy so far to limit the urban expansion and the controlling mechanism either. Therefore, the rural village development committees nearby are also going through spatial transformation in the urbanizing process. In regard to the spatial pattern of Kathmandu valley, it has many agricultural based traditional Newar towns at its urban periphery such as Harisiddhi, Thaiba, Chapagaun, Lubhu, Thecho, Bungamati, Khokana, Kirtipur. Lubhu, the study area is situated in the close proximity of urban

\footnotetext{
*Corresponding author: Rijina Bajracharya

Department of Architecture, Khwopa Engineering College,

Libali-8, Bhaktapur, Nepal

Email: riji_rijina@yahoo.com

(Received: 2016 Sept 03 Accepted: 2016 Nov 06)
}

JScE Vol. 4, April 2017

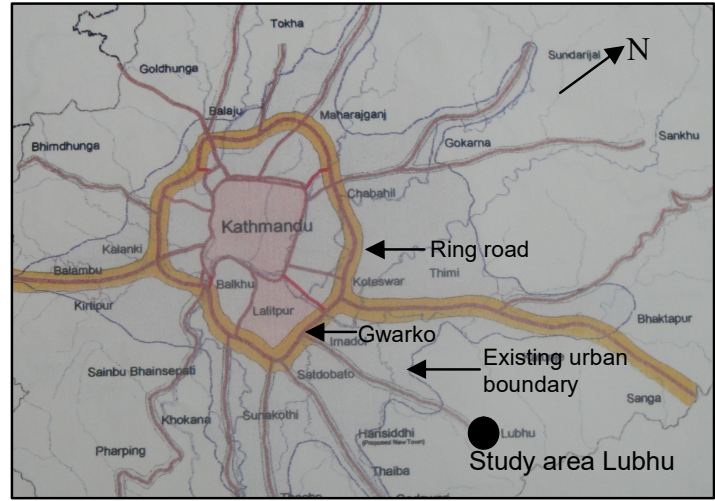

Fig 1 Study area in the urban context

(Source: KVTDC (2002))

boundary of Lalitpur district, $6 \mathrm{~km}$ east from Gwarko, Ring Road as located in Fig 1. According to the data of census 2001, Lubhu has the population of 7610 and total households being 1439. The population is predominantly a Newar society as $61.59 \%$ of total population belongs to the Newar community. The total land area is $7.65 \mathrm{sq} \mathrm{km}$ where more than $50 \%$ of the land is being used for agriculture. In 2008, the population increased to 8272 and the number of household to 1614 
(Lubhu village development committee Profile 2008)

Lubhu was a fortified town confined within four dhoka (town gates) as other Newar towns in
As Pant (2002), discusses the three levels of spatial hierarchy in the spatial organization of traditional Newar town during his study in Thimi, Lubhu also reflects nearly similar type of spatial hierarchy as Chhen (individual dwelling), Nani (residential

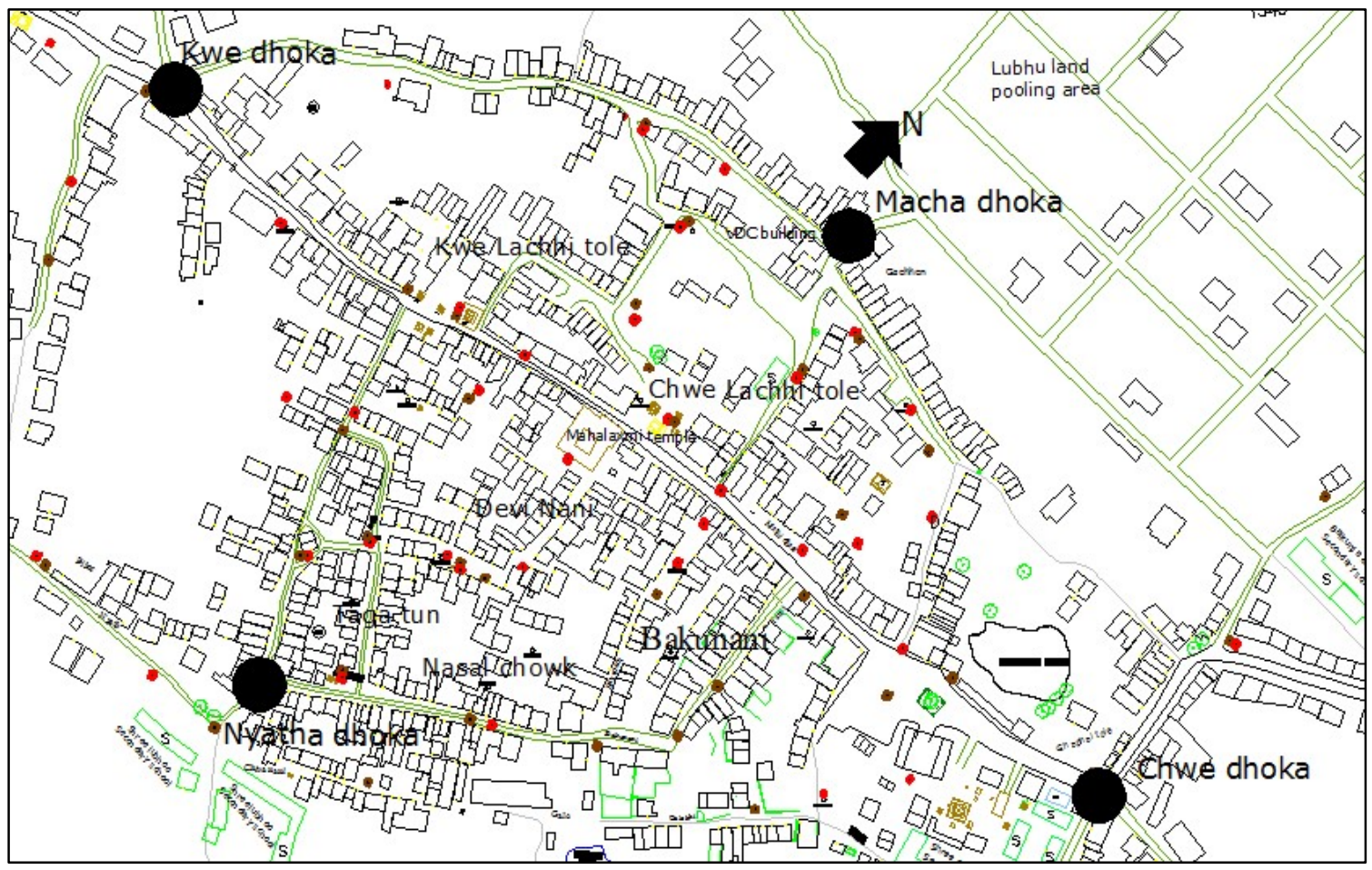

Fig 2 Boundary of Traditional core of Lubhu within four town gates (Source: Department of Housing and Urban development, Base maps of Kathmandu valley, 1999)
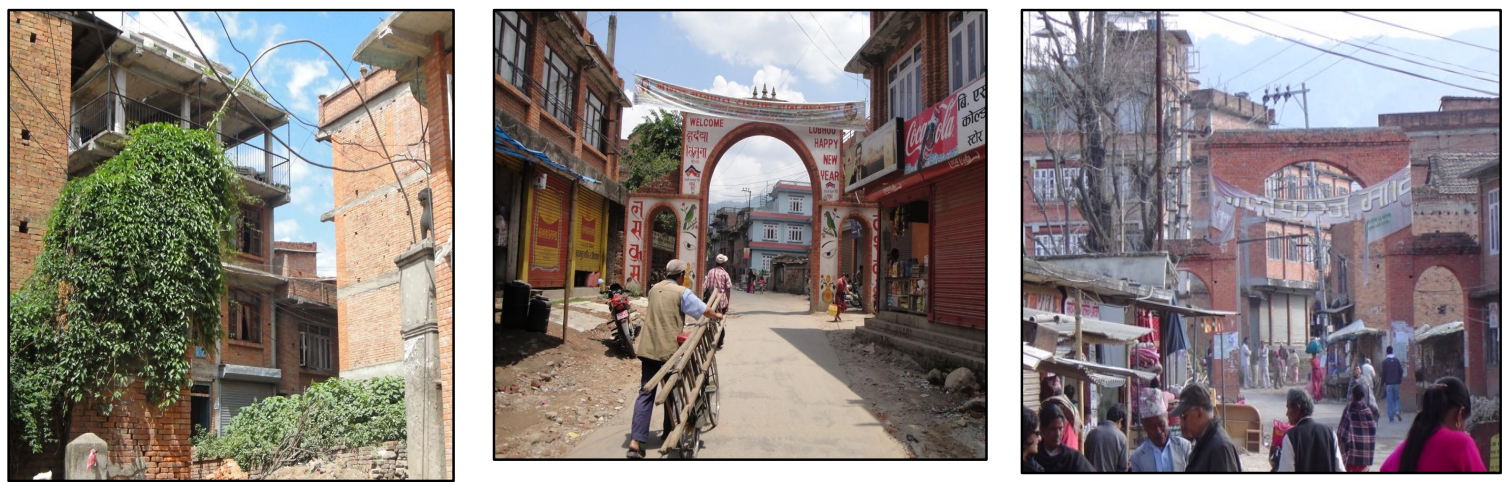

Fig 3 Town gates Kwe Dhoka, Nyatha Dhoka \& Chwe Dhoka (from left to right)

Kathmandu Valley. The stone foundations of fortified walls having $1.2-1.5 \mathrm{~m}$ width were found $2.4-2.7 \mathrm{~m}$ below the ground level during the construction of one of the residences in Lubhu in 1974 A.D. Shrestha (1997, p.21). The location of four town gates at four directions are shown in Fig 2 and among them, the three town gates existed till date are shown in Fig 3. court) and Tole (Neighborhood court). This settlement is rich both architecturally and socioculturally with the presence of temples, shrines, hiti (traditional water spouts), wells, ponds, dhoka (town gates), sattal/pati (traditional shelters for taking rest) and courts as open spaces. The settlement pattern with street network of the study area is shown in Fig 2 and some typical old photos are shown in Fig 4. 

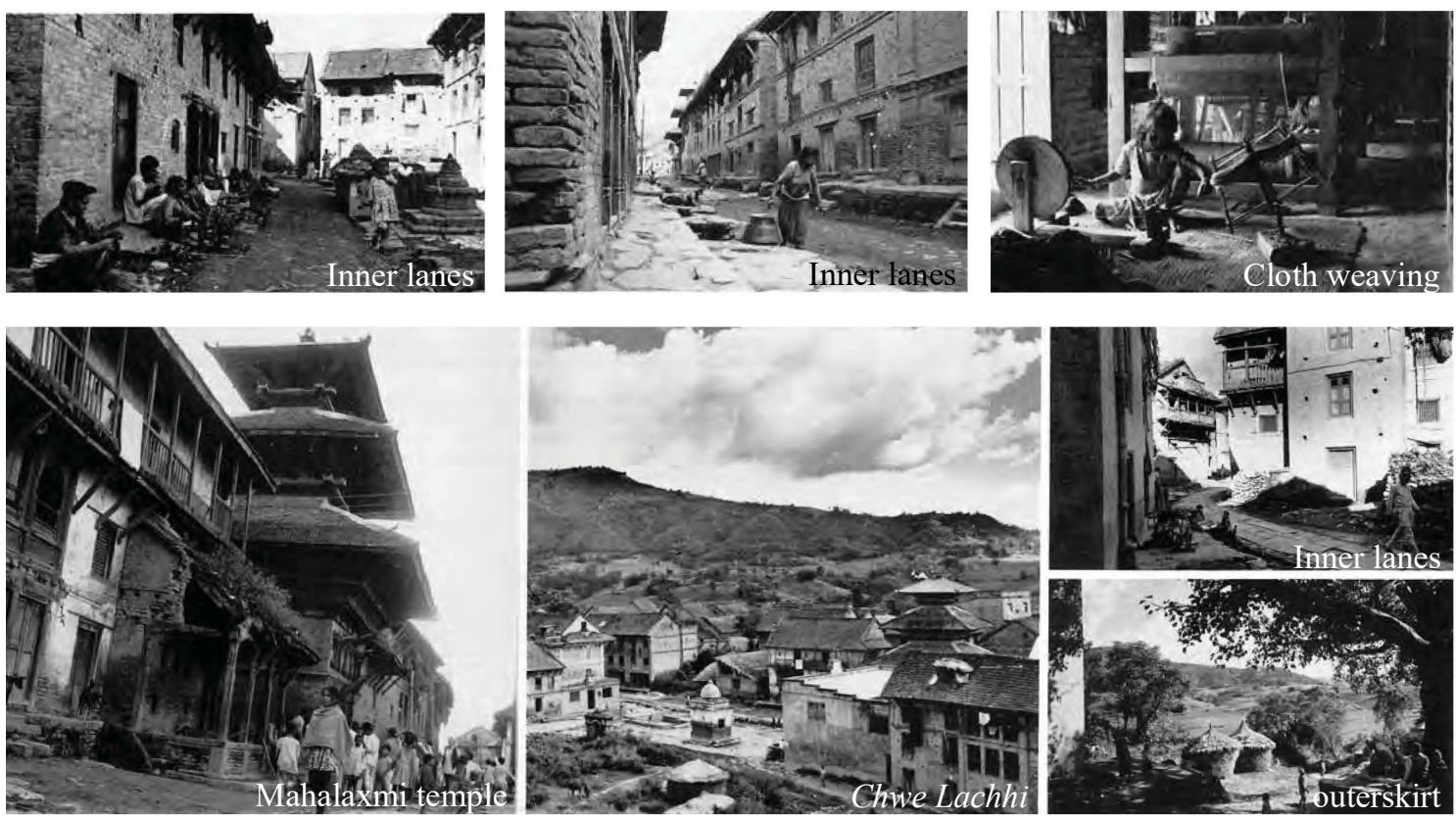

Fig 4 Views of Lubhu Settlement (Source: Pruscha, C. (Ed.). (1975))
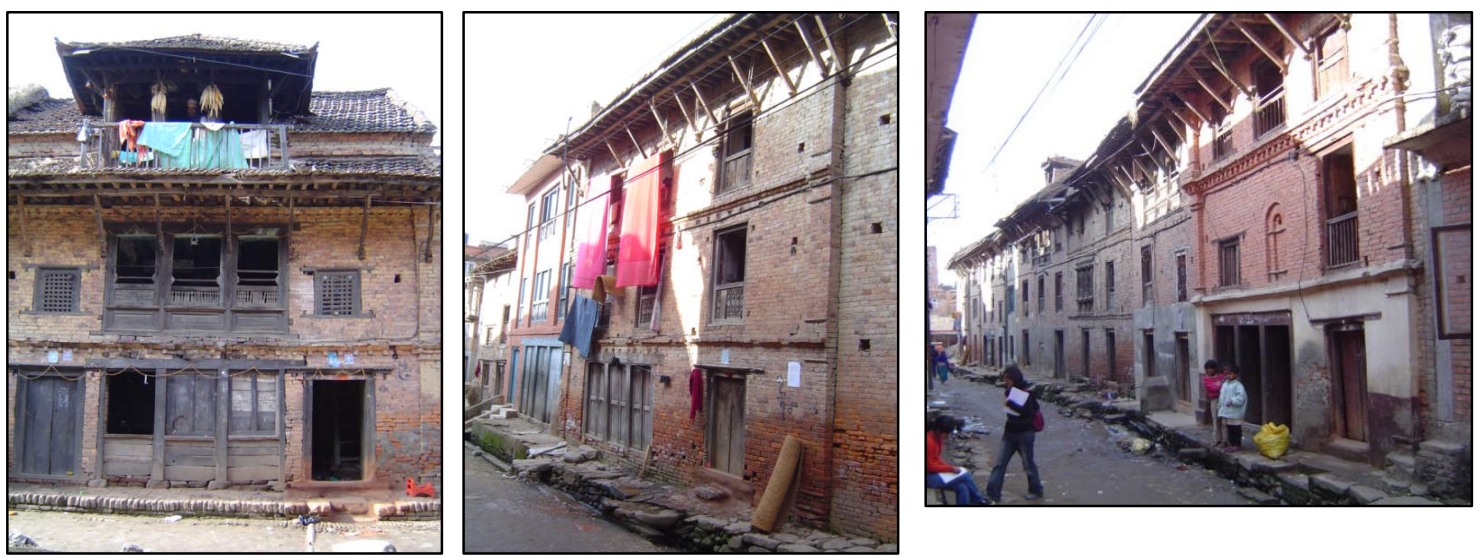

Fig 5 Typical Traditional facades in the study area (Source: Institute of Engineering, Department of Architecture, 2000 Batch Conservation Studio)

\section{Literature Review and Theoretical Framework}

In regard to the spatial transformation, as Bobic (1990, p.82) explains "When there is notable incompatibility between the rhythm of activities and the form of the space, when it is not possible to adjust the existing with the new, then there is the spatial transformation". On the other side, "non spatial transformations include changes in the type of activity, the manner of operation, i.e. changes in the way the existing spatial structure is used, thereby adapting the existing qualitative factors and time in the given space". He defines rhythms as the main stay of the spatial structure's development and the cause of transformation, determining character and meaning. "Rhythm is the basic measure of urban dynamics expressed spatially and non spatially by time intervals " Diurr (1968 quoted in Bobic 1990, p.70).

Although transformation is the natural phenomenon, Doxiadis (1982 quoted in Bobic 1990) argues that every urban structure has the capacity for internal dynamic equalization through the mobility of its 
components and interaction. The power of structure is of an auto regulative in nature which develops spatially in two ways.

The first one is intensively as internal transformations where the characteristics of spatial structures change within the encompassed territory by becoming denser, changing the use of the space, reforming and replacing the existing spaces etc. The second is extensively, and it happens outside the encompassed territory when the potentials of the structure are exhausted or when it is superseded by a new basic characteristics (Bobic,1990). Either intensively or extensively, the auto regulation is just the temporal adjustment of the ongoing dynamism of spatial structures as he argues.

The transformation in the study area is also going through both intensive and extensive transformations in course of time. The transformation in the existing built space within the traditional town boundary in terms of spatial structures, and building use indicates the intensive one, whereas the transformation happening in the vacant agricultural land beyond the existing town boundary signifies the extensive one.

\section{Methodology}

Prior to the analysis of transformation in the study area, the photographic observation was carried out to see the ongoing changes in the built form. During field visit, the changes happening in the lowest spatial structure (Chhen) and elements of major spatial structures in neighborhood courts (Tole) were the visible part of internal transformation.

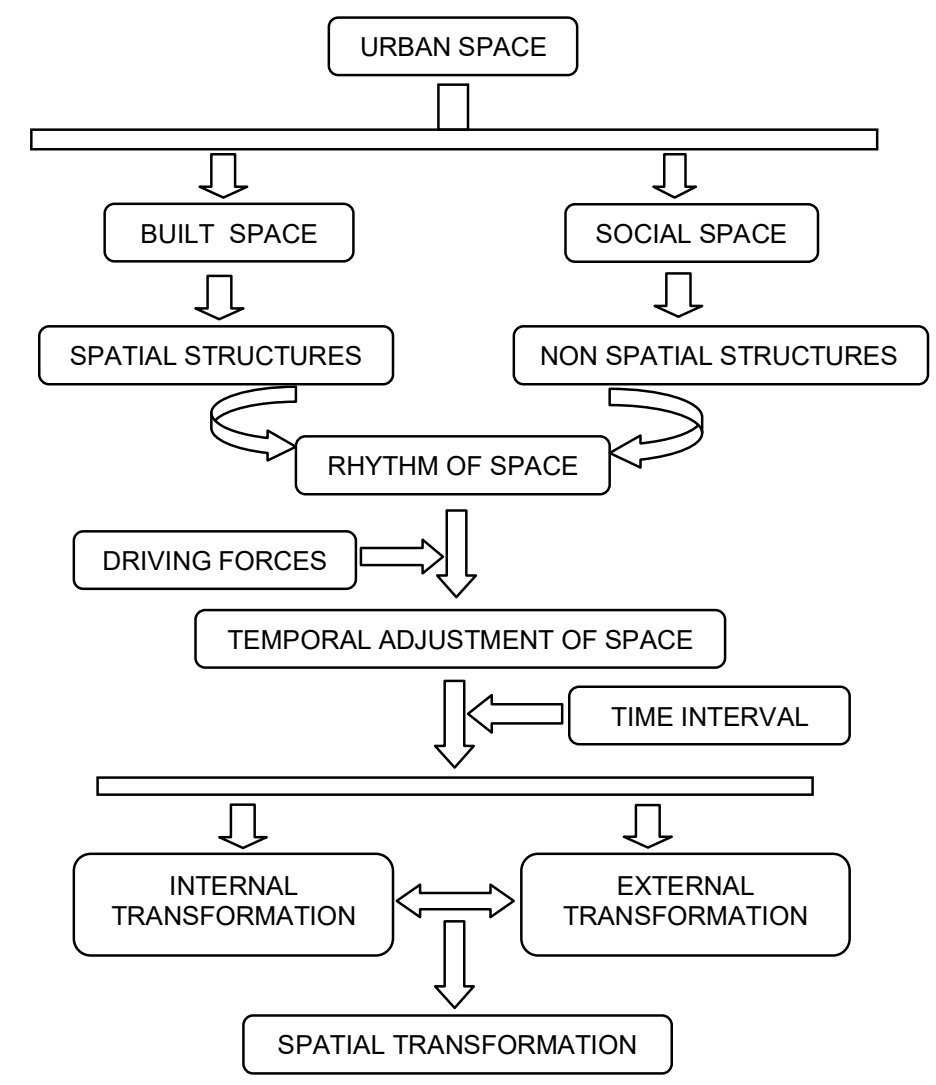

Fig 6 Theoretical Framework 
Further, the focus group discussions among old people were conducted to identify the areas of transformation within the traditional settlement as changes were in their memory rather than in a documented data which further helped to understand the internal transformation. The household questionnaire survey was conducted to know the driving forces and impacts of the internal transformation. Regarding the external transformation, the data from household survey helped to comprehend the land holdings, land fragmentation and land transaction in the study area. The interviews with local brokers helped to identify the cases and locations of land fragmentized area.

From the land survey office, old and new cadastral maps of such cases (as suggested by locals \& brokers) were collected to analyze the fragmentation process. Among them the typical examples for broker led and inherited land subdivision were selected for detail analysis. Further, the satellite images of different time frames were collected from the department of survey, to figure out the development pattern beyond the core settlement. Simultaneously secondary data was also reviewed from different resources.

\section{Analysis on Spatial Transformation}

\subsection{Analysis on Transformation in Built Space}

\subsubsection{Transformation in Lowest Spatial Structures (Chhen) and its Impacts}

In Lubhu, as shown the courts \& inner lanes in Fig 4 \& $7 \mathrm{a}$, the traditional houses based on traditional design and construction technology used to be dominant during 1970s. But from the survey, the ratio is found to be almost $50-50$. Only $46 \%$ houses are found to be in traditional design with mud brick construction whereas $49 \%$ of the houses have been built in reinforced cement concrete (RCC) constructions. And left $5 \%$ of the houses have also changed the façade with different treatments. The façade treatment includes changes in construction materials from sun dried bricks to baked bricks, from lime or mud to cement mortar or from brick exposed facades to cement plastered as shown in Figs 7 (b) \& 7 (c) and 8 (a) \& 8 (b).

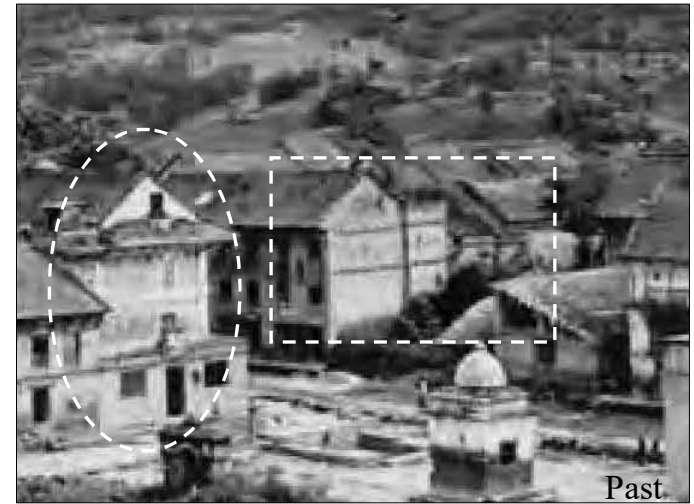

Fig 7 (a) Chwe Lachhi (Source: Pruscha, C. (Ed.). (1975))

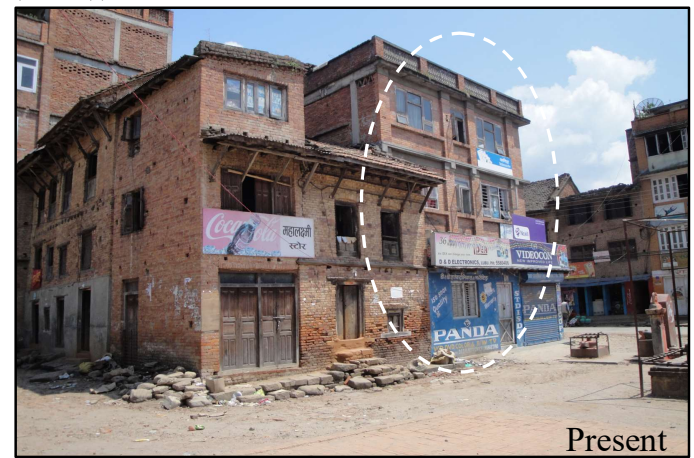

Fig 7 (b) Changes in building (dotted circle part in Fig 7 (a))

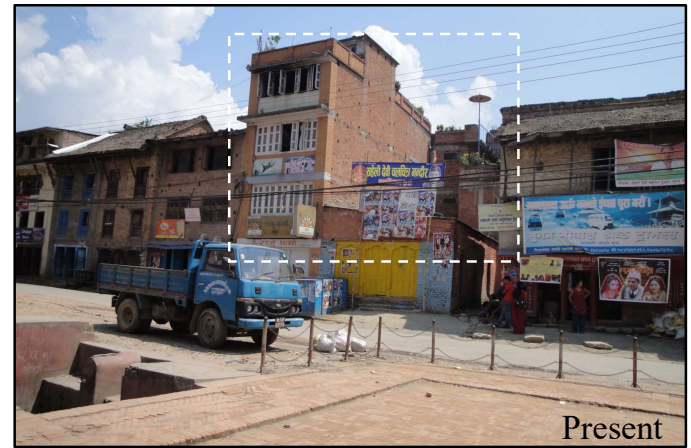

Fig 7 (c) Changes in building (dotted rectangle part in Fig 7 (a))

Although the transformation is in this lowest spatial unit has been taken as very minor interventions by the local people which include variations in the window/door opening (Fig 9 (a)), changing skyline (Fig 9 (b)), vertical division of houses (Fig 9 (c)), new construction with plinth level and floor height different than the attached buildings (Fig 9 (d)), it has affected the pleasing streetscape. In a long run, it may also weaken the structures making them more susceptible to substantial damage in case of earthquake and may make the whole community more vulnerable in the time of disaster. 


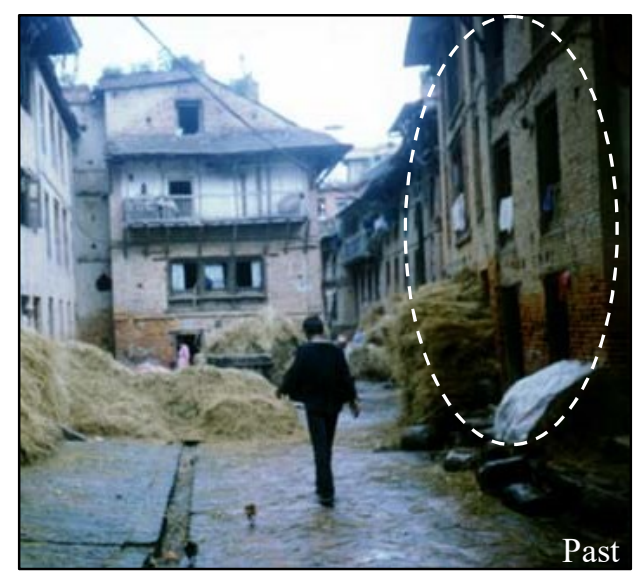

Fig 8 (a) Mud brick façade building at Nasal chowk in $60 \mathrm{~s}$

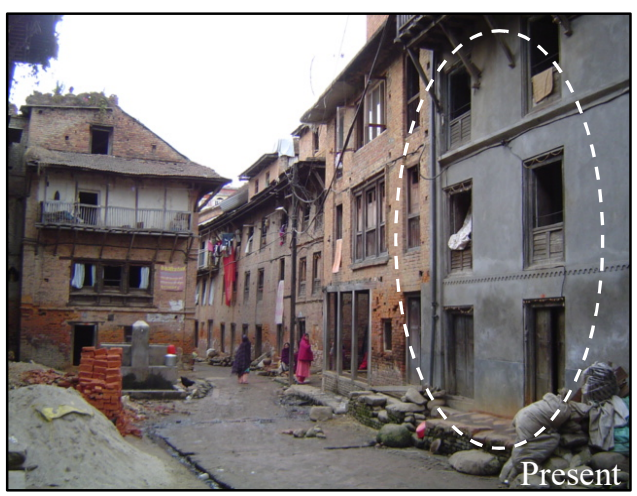

Fig 8 (b) Change of mud brick façade building to cement plastered (dotted part in Fig 8 (a))

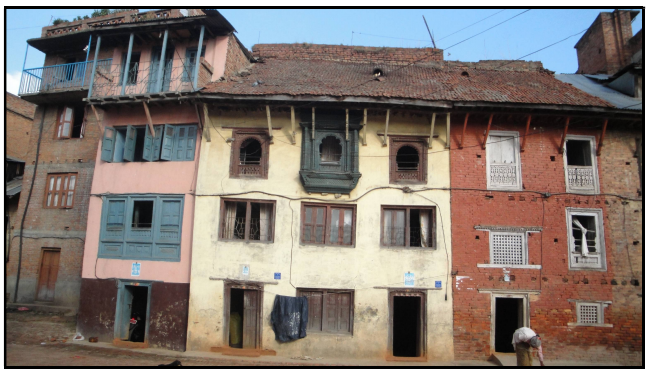

Fig 9 (a) variation in openings of the buildings

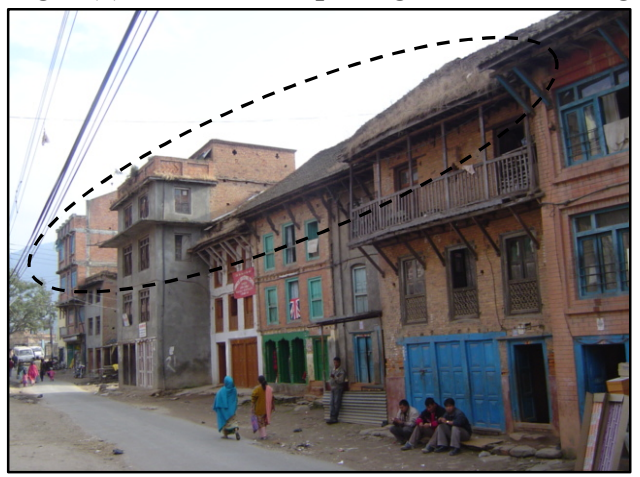

Fig 9 (b) Changing skyline in street facade

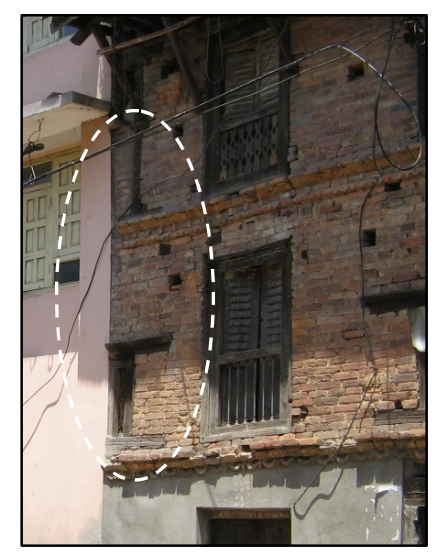

Fig 9 (c) Vertical division in buildings

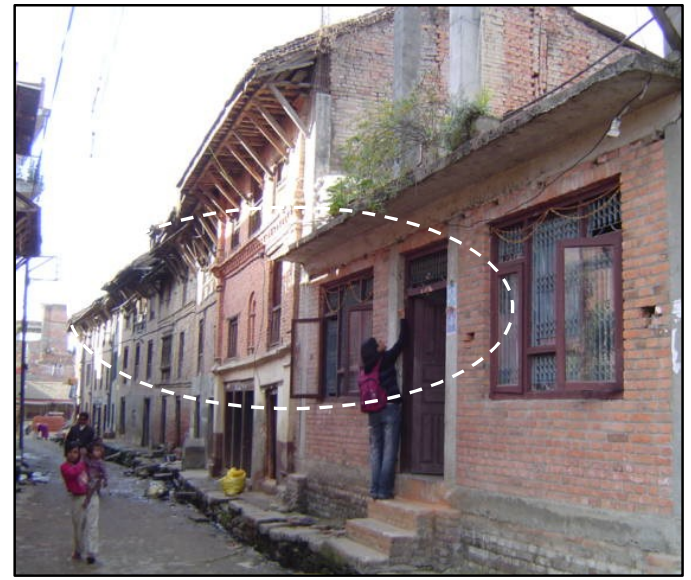

Fig 9 (d) Change in floor height in old \& new constructions

\subsubsection{Transformation in courts (Tole \& Nani) and its Impacts}

The renovation by imposing unfamiliar material like RCC other than prevailing mud, brick, wood in temples, monuments, pati, hiti, wells, public buildings, not only wipes out the aesthetic quality of the space but also fades the true spirit of the spatial organization of neighborhood and residential courts. Despite of their physical existence, their traditional values and soul are slowly disappearing.

For example the external wall of the Narayan temple at Kwe Lachhi (Fig 10 (a)) has been partially cement plastered, the traditional Hiti at Chwe Lachhi (Fig 10 (b)) which used to be brick exposed and stone claddings has been renovated using cement concrete, the traditional tiled roof of the rest houses at Kwe Lachhi (Fig 10 (c)) has been replaced by Corrugated Galvanized Iron (CGI) sheet and the traditional pati besides Mahalaxmi temple (Fig 10 (d)) has been changed during renovation (Fig 10 
(e)). The emerging RCC buildings as new constructions in Chwe Lachhi as shown in Fig 11 is disturbing the vibrant streetscape and traditional ambience of the courts. Likewise the Chwe Pukhu (pond) located outside the chwe dhoka in the past has been transformed into the traffic island with bus parking facilities as shown in Fig 12. These disharmonious alterations are increasing in an alarming rate in the study area threatening the identity of the very place.

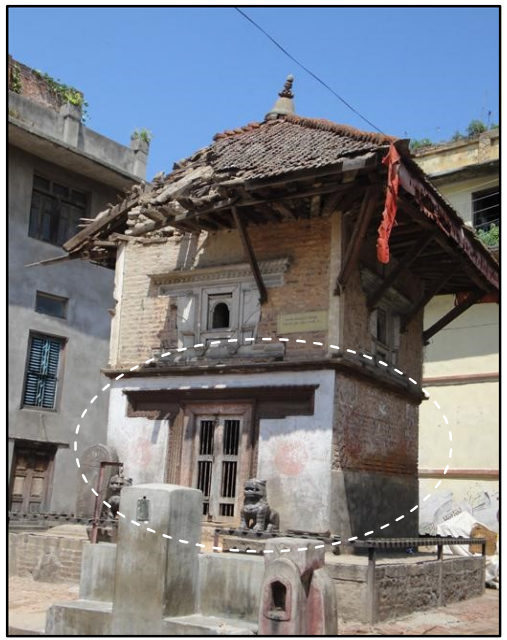

Fig 10 (a) Narayan temple at Kwe Lachhi

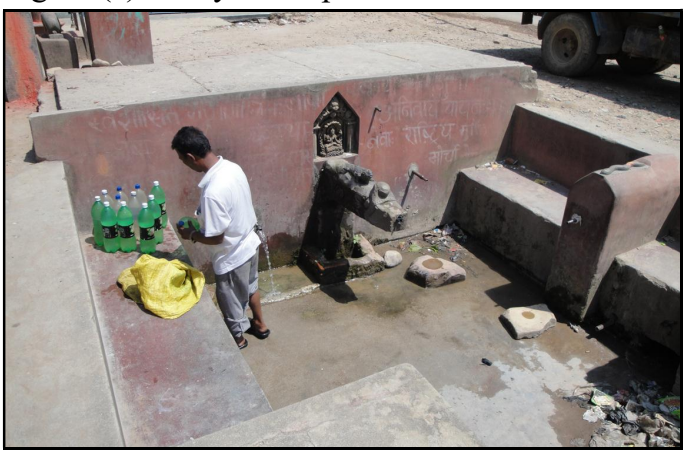

Fig 10 (b) Hiti (cement plastered) at Chwe Lachhi

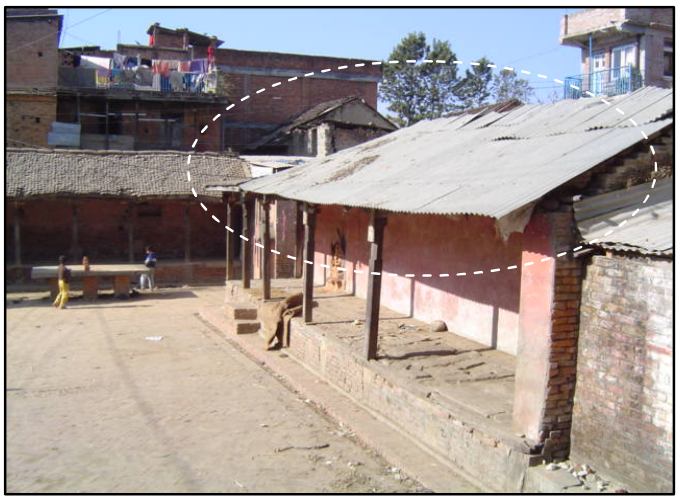

Fig 10 (c) CGI sheet on the roof of Pati at Kwe Lachhi

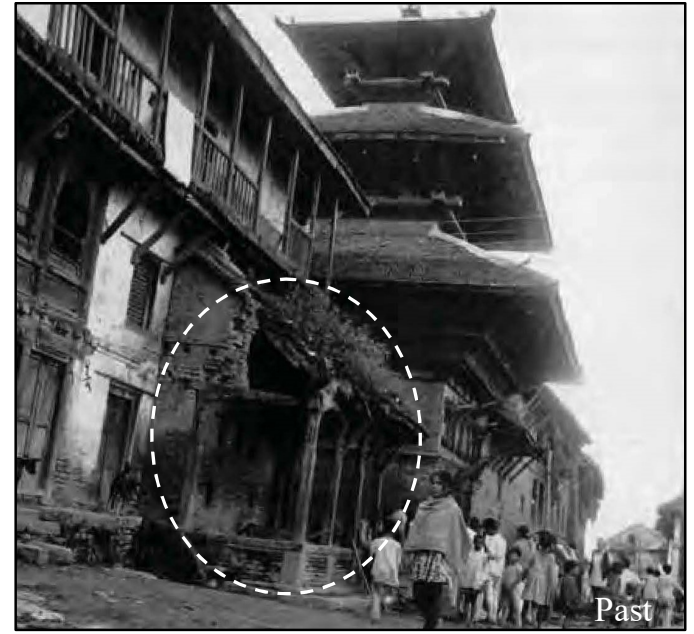

Fig 10 (d) Mahalaxmi temple pati in 1970s (Source: Pruscha, C. (Ed.). (1975))

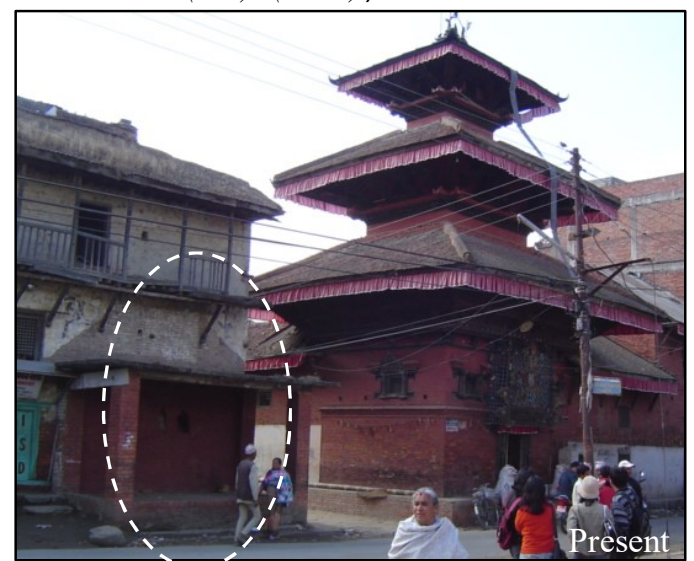

Fig 10 (e) Renovated Mahalaxmi temple pati (dotted part in Fig 10 (d))

\subsection{Analysis on Transformation in Land}

Kivell (1993) argues, land as one of the major components of spatial structure which determines the settlement pattern of any city. For the study area, where more than $50 \%$ of land is being used for agriculture, it is worth to see the changes happening in land to interpret the spatial transformation.

Three types of land related issues have been identified in the study area as an external transformation. The first one is the land pooling program of government completed in 1997, the second is the ribbon type of sprawl development along the major road as new developments and third is owner led \& broker led land fragmentation. The land pooling site, sprawl development \& typical examples of land fragmentation are located in Fig 13. 


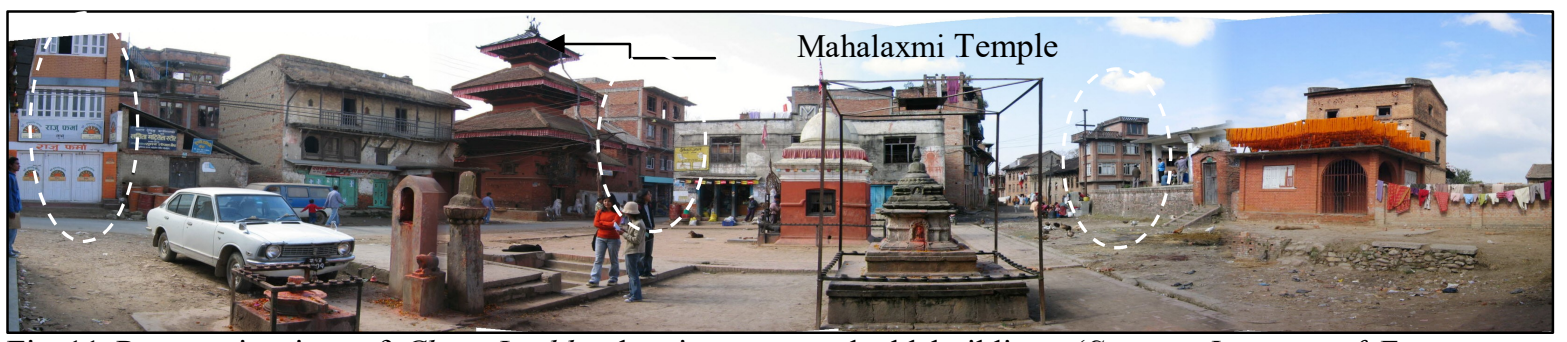

Fig 11 Panoramic view of Chwe Lachhi showing new and old buildings (Source: Institute of Engineering, Department of Architecture, 2000 Batch Conservation Studio )
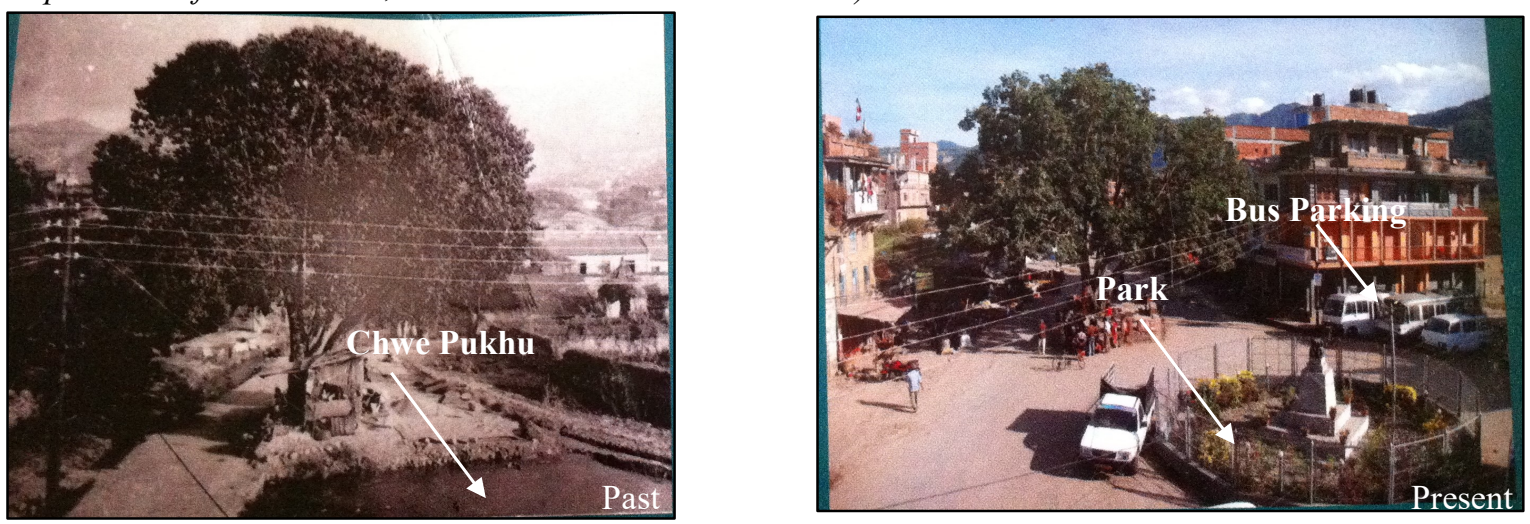

Fig 12 Chwe Pukhu area in the 70s (left), Transformation into Lubhu Bus park (right)

\subsubsection{Land Pooling Program of Government}

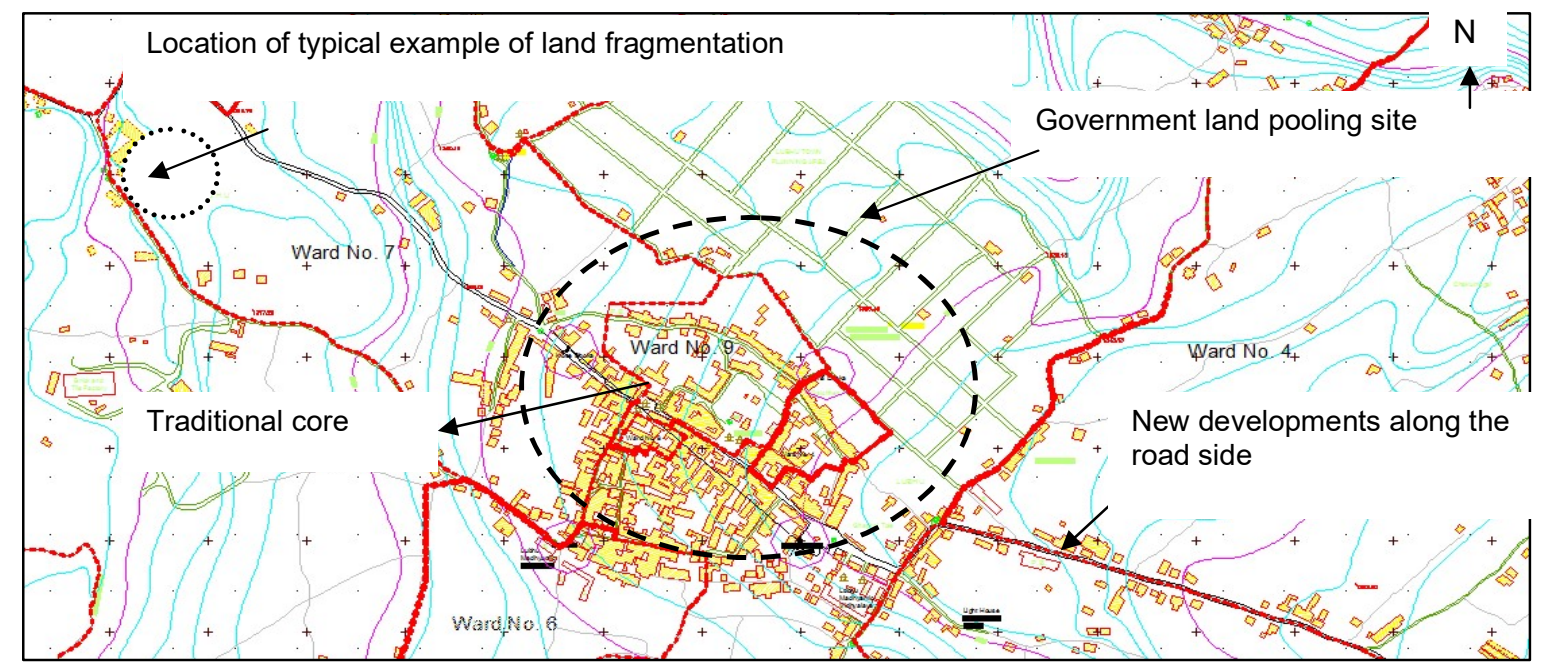

Fig 13 Location showing typical land related issues with respect to the core settlement (Source: Base maps of Kathmandu valley, Department of Housing and Urban development, 1999)

Regarding the land pooling by government, the total site was 269 Ropani 13 Anna 1 Paisa 0 Dam (137271.56 sq.m) as shown in Fig 13. As per the byelaws of Lubhu land pooling program, the owner of the developed plots could neither sell nor transfer the ownership but should build house within five years from the date he got the plot (Lubhu Land pooling Program, 1997).
During the site visit, which is almost 10 years after the completion of the project, only few plots have buildings built on and big chunk of plots are found vacant. The satellite image of 2010 as shown in Fig 14 illustrates the situation. One of the reasons for this is people are not strictly following the norms but speculating the land value. 


\subsubsection{Sprawl Development}

From the series of satellite images in Fig 14, the linear development along the road axis can be found immediate after the core settlement in an ad hoc basis. The survey result also shows that $65 \%$ of the households who have constructed the buildings at new sites did so, because of the facility of roads and good vehicular access since they can have commercial use of their residences and make good money.

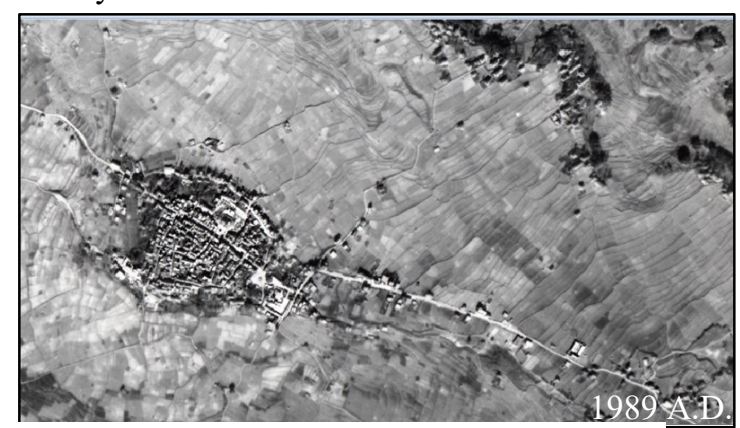

Fig 14 (a)

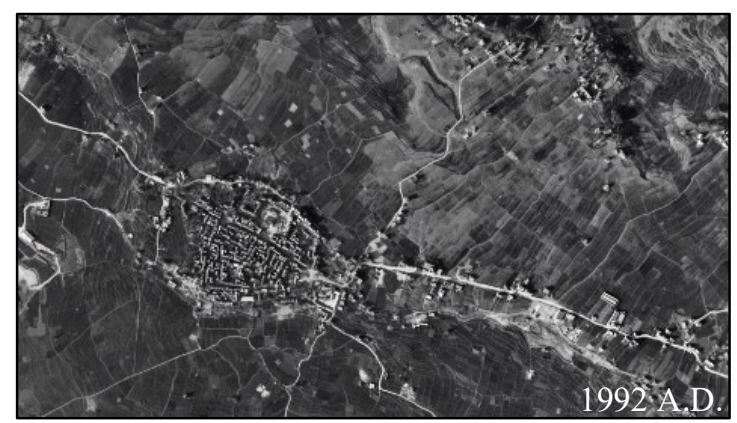

Fig 14 (b)

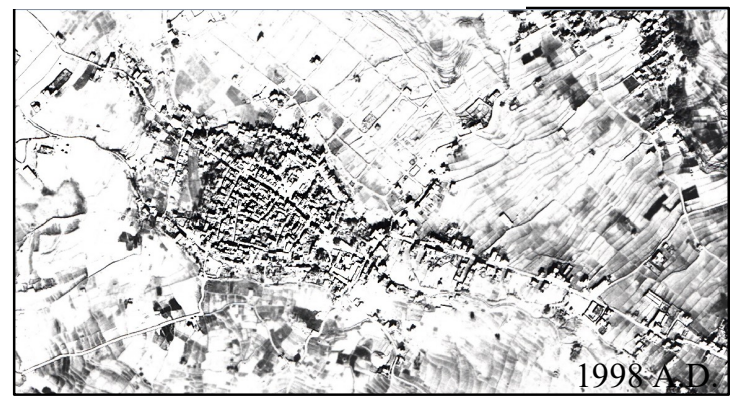

Fig 14 (c)

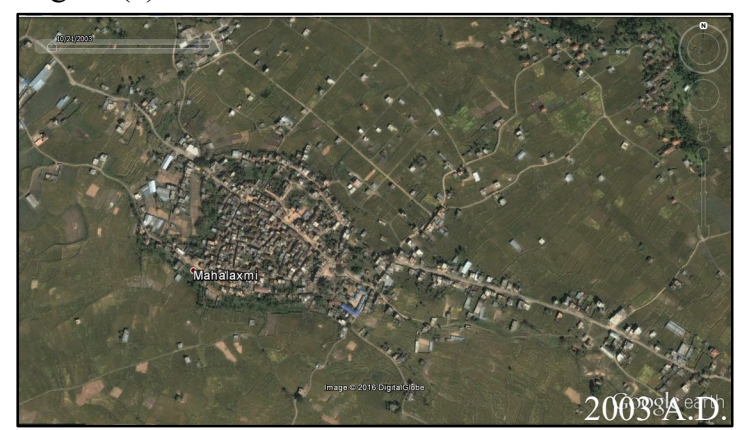

Fig $14(d)$

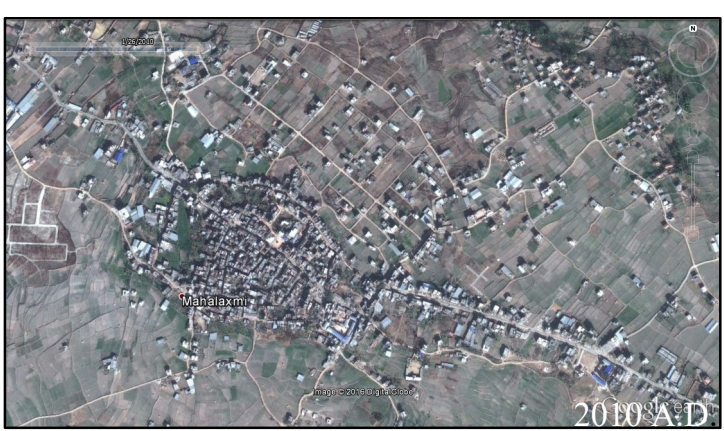

Fig 14 (e)

Fig 14 Satellite images from different time periods (Source: Survey Department, Minbhanwan)

\subsubsection{Land Fragmentation and its Impacts}

From the household survey, it is found that $84 \%$ of the total respondents have land parcels in study area and there is growing trend of land fragmentation as responded by $80 \%$ of the respondents. The typical example of land fragmentation is taken from ward no 7 and the cadastral map is shown in Fig 15. Their locations are already shown in Fig 13.

For the case of land parcel 155, as shown in Fig 15, it used to be big chunk of land. Later, the group of brokers bought it and fragmented the land into 19 smaller land parcels ranging the area from 2 Anna 2 paisa (79.49 sq.m) to 12 Anna 1 Paisa 3 Dam (395.46 sq.m) as shown in the table 1. These land parcels are kept for sale.

The land parcel no. 156 as shown in Fig 15 is fragmented during the inherited property division among the siblings in one of the local families. The family tree and the division of land parcels are shown in Fig 16.

Thus, this type of individually driven land development process has encouraged informal land business and manipulated the land value also. It made the locals assumed that that there is no need of trained land developers rather anyone can be land developers and make money. However, this little knowledge might have impact in the distribution and management of infrastructure in future affecting the whole urban scenario. 

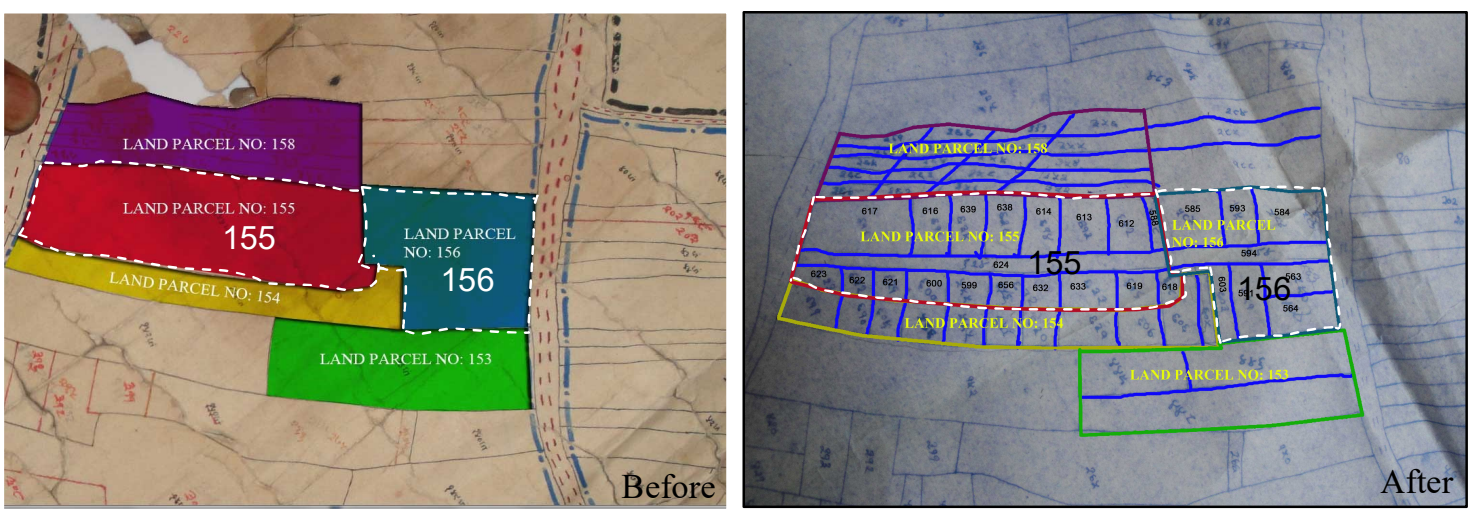

Fig 15 Cadastral maps showing land parcels (155 and 156) before and after fragmentation (Source: Land Survey Office, Lalitpur)

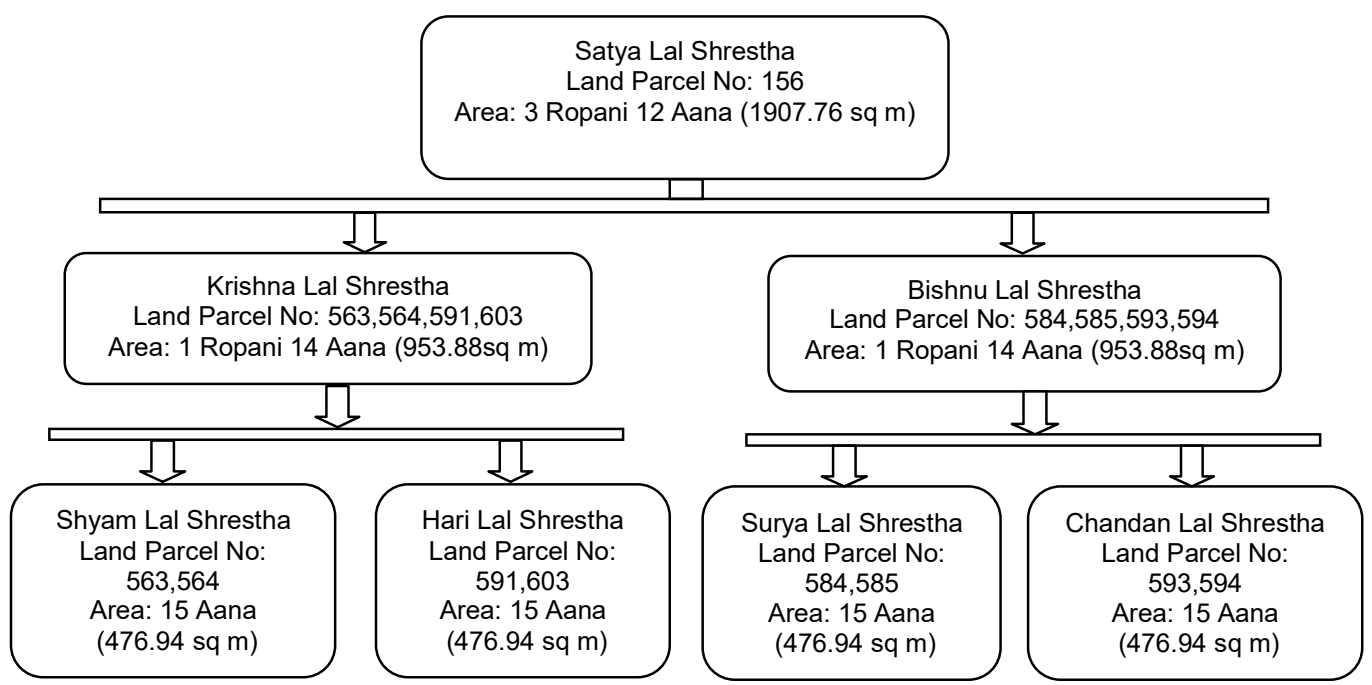

Fig 16 Inheriting property division of land parcel No.156 (Source: Land survey office \& field survey, 2010)

\subsubsection{Land Value and its Impacts}

In the study area, the land value that has been currently used by the informal private sector is comparatively higher than that of the value determined by the government as shown in table 2 . The difference in land values indicates the growing individual efforts in land business and also shows the growing demand of land. It has also stimulated the land transaction and land speculation in the past $10-15$ years as cited by the $95.6 \%$ of the respondents. The local people are found to be interested to sell land because of the increasing land value as $29 \%$ of the respondents did so. At the same time the non local people are being interested to buy land in the study area because it has good linkage with Ring road and the Araniko highway. They believed that the study area has high potential in terms of land market in future. Instead of constructing house for which the land was sold to them, they cultivated the land and speculated the land price to be increased so that they could sell in high profit.

\subsection{Driving Forces for Transformation}

As explained by Bobic (1990, p.82), spatial transformation cannot take place without the non spatial transformation. The incompatibility between the rhythm of activities and the spatial structures leads the spatial transformation. For the study area, the non spatial structures mean the life styles of the people \& their daily activities which are 
Table 1 Broker led land fragmentation of Land Parcel No. 155

\begin{tabular}{|c|c|c|c|}
\hline S.N & Land Parcel No. & Land area ( Ropani-Anna-Paisa-Dam) & Area in (sq m) \\
\hline 1. & 588 & $0-2-2-0$ & 79.48 \\
\hline 2. & 612 & $0-5-1-0$ & 166.90 \\
\hline 3. & 613 & $0-5-3-0$ & 182.80 \\
\hline 4. & 614 & $0-5-2-0$ & 174.85 \\
\hline 5. & 638 & $0-5-1-0$ & 166.90 \\
\hline 6 & 639 & $0-5-1-0$ & 166.90 \\
\hline 7. & 616 & $0-5-0-0$ & 158.95 \\
\hline 8. & 617 & $0-11-1-0$ & 357.64 \\
\hline 9. & 624 & $0-12-1-3$ & 395.39 \\
\hline 10. & 523 & $0-2-2-0$ & 79.48 \\
\hline 11. & 622 & $0-2-2-0$ & 79.48 \\
\hline 12. & 621 & $0-2-2-0$ & 79.48 \\
\hline 13. & 600 & $0-2-3-0$ & 87.43 \\
\hline 14 & 599 & $0-3-0-0$ & 95.37 \\
\hline 15 & 656 & $0-3-0-0$ & 95.37 \\
\hline 16 & 632 & $0-5-3-0$ & 182.80 \\
\hline 17. & 633 & $0-5-1-0$ & 166.90 \\
\hline 18. & 619 & $0-3-3-0$ & 119.22 \\
\hline 19 & 618 & $0-1-1-0$ & 39.74 \\
\hline & Total & $5-10-1-3$ & 2875.08 \\
\hline
\end{tabular}

(Source: Land Survey Office, Lalitpur, \& field survey, 2010)

Table 2 Land value per Ropani determined by government in NRs \& Market Land Value per Ropani in NRs

\begin{tabular}{|c|c|c|c|c|c|c|}
\hline \multirow[t]{2}{*}{ Land type } & \multicolumn{3}{|c|}{$\begin{array}{l}\text { Land value determined by Government in } \\
\text { NRs }\end{array}$} & \multicolumn{3}{|c|}{ Market Land value in NRs } \\
\hline & $2007 / 2008$ & $2008 / 2009$ & $2009 / 2010$ & $2005 / 2006$ & 2006-2009 & $2009 / 2010$ \\
\hline $\begin{array}{l}\text { 1. Plots from } \\
\text { government } \\
\text { land pooling } \\
\text { program }\end{array}$ & $1,250,000$ & $1,375,000$ & $1,850,000$ & $5,952,000$ & $7,200,000$ & $9,600,000$ \\
\hline $\begin{array}{l}\text { 2. Attached } \\
\text { with metallic } \\
\text { road }\end{array}$ & 900,000 & 990,000 & $1,500,000$ & $10,000,000$ & $12,000,000$ & $16,000,000$ \\
\hline $\begin{array}{c}\text { 3. Attached } \\
\text { with unmetallic } \\
\text { road }\end{array}$ & 450,000 & 500,000 & 800,000 & $4,960,000$ & $6,000,000$ & $8,000,000$ \\
\hline $\begin{array}{l}\text { 4. Track/foot } \\
\text { trails }\end{array}$ & 250,000 & 275,000 & 450,000 & $3,472,000$ & $4,200,000$ & $5,600,000$ \\
\hline 5. Without road & 125,000 & 140,000 & 210,000 & $1,488,000$ & $1,800,000$ & $2,400,000$ \\
\hline
\end{tabular}

(Source: Land Revenue Office, Lalitpur\& Information collected from brokers during field survey,2010) 
changing with time. Following are the driving forces (identified through the household survey) acting as the catalysts in stimulating non spatial structures and transforming the spatial layout of the study area.

\subsubsection{Accessibility and Mobility}

Along with the improvement of vehicular road in 1990 A.D. connecting this area to existing urban boundary, the accessibility became ease comparatively to the past when people had to walk. Further, the survey shows that $50 \%$ of the total respondents have their own vehicles which increased their mobility apart from the public transportation means. The survey shows that $62 \%$ of total respondents visit city centers daily and others being weekly and monthly for trade, shopping, education, health reasons etc. It shows that people are being more familiar with the urban ambience, urban culture and in terms of built spaces and activities. Their exposure to these factors has been reflected in their own daily lives despite the rural settings.

\subsubsection{Modern Amenities and Changing Life Styles}

The easy access to different means of telecommunication helped the locals to keep in touch with the world beyond their native place. Specially, the new generations, rather than spending time on streets and community spaces, like to sit in their rooms enjoying with television and internet. Along with the changes in their activities they prefer to have such RCC building and layouts and are also fascinated by the culture which is popular in other cities. The survey data shows that $38 \%$ of the total respondents cited that the uncomfortable old houses (such as the low ceiling heights, lack of adequate light and cross ventilation) as the reasons for leaving them and building new ones. The old generations are fine with those buildings but not the young generations because of their changing life styles. It encourages having changes in their own built spaces.

\subsubsection{Growing Nuclear Families}

The survey shows that $67 \%$ of households have nuclear families, and remaining 33\% have joint families in the study area. $49 \%$ of the households left their native places house because of the ancestral property sub division. Thus the breakdown of extended families to nuclear families leads to division of property either the building itself or agricultural land and transforms the spatial layout. And also the survey shows that $9 \%$ of total respondents left their native houses because of the growth in family size. So, the increase in population is another reason behind the change in the built space.

\subsubsection{Decreasing Agricultural Market}

Agriculture used to be primary occupation of local residents in the past. But the survey shows only $16 \%$ of total respondent, entirely relied on agriculture, whereas $81 \%$ made agriculture as the supporting occupation with their major involvement in other occupations. $84 \%$ of the total respondents agree that there is decline in agricultural market for the last 510 years due to the poor facilities of irrigation and low productivity. It made people think about alternative occupations and good way to get profit from their land. Land business has become the one, as it is found that $30 \%$ of the total respondents sold land to make good money and $54 \%$ did so to build new house and give on rent and have profit.

\subsubsection{Affordability and Weak Local Institutions}

The urbanization in the city center has created a demand for housing plots and basic services. Those who cannot afford land in municipal areas prefer to stay on the fringe areas of the cities and villages since the living cost is relatively low (Settlement Pattern, 2010). Besides getting cheaper housing plots, another motivating factor for new migrants to settle in rural areas is the weak institutionalization of local village development committee in terms of issuing building permits. According to the staff of the very office, building permit is required for any new constructions within the existing traditional settlement and new sites in the periphery. However, people are reluctant to follow so far since there is no strict enforcement as such.

\subsubsection{Individual Development Efforts}

Another reason behind the spatial transformation is the emerging informal land market and the division of land. The broker led land division practice and the owner led land division practice are changing 
the scenario of the agricultural land in the study area as discussed in section 4.2.3. Land brokers are rooted in every society as there are no strict criteria to be so. The individual land developers without proper training, skill knowledge and planned vision for land development have caused the random fragmentation of land leading to the unplanned spatial layout.

\section{Conclusion}

With the increasing trend of urbanization, the spatial transformation of Lubhu, one of the traditional towns located at the proximity of urban boundary of Lalitpur has demonstrated two distinct forms of spatial transformation; the intensive transformation and the extensive one. As the intensive transformation, the study has revealed gradual change in built forms, streetscape and the ambience of public spaces driven by changing life styles in course of time. The extensive transformation in Lubhu has set its pace through emerging linear built up areas along the extended vehicular roads close to the traditional core and sparsely built along the new access roads to introduce commercial activities in their residences and also to give on rent. In addition, the land readjustment through government led land pooling, land fragmentation through broker led private plotting and division of land owner's inherited properties to siblings have been prominent features of extensive transformation in this case.

The slow pace of development at government led land pooling project area has raised some queries on its effectiveness. On other hand sprawled development is also taking place in an ad hoc basis beyond the so called planned areas. It is clearly demanding review of existing policies and practices to ensure better and planned development in future.

\section{References}

[1] Bobic, M. (1990). The Role of Time Function in City Spatial Structure. Aldershot, England: Gower Publishing Company Limited.

[2] CBS. (2009). Nepal in Figs, Government of Nepal, National Planning Commission Secretariat. Kathmandu: Central Bureau of Statistics Publications

[3] Hosken, F. P. (1974). The Kathmandu Valley Towns, a Record of Life and Change in Nepal. New York: Weatherhill.

[4] Kivell, P. (1993). Land and the City: Patterns and Processes of Urban Change. London: Routledge.

[5] KVTDC. (2002). Kathmandu Valley Long Term Development Concept (Kathmandu Vision 2020). Anamnagar, Kathmandu: Pioneer Concept and Printers.

[6] Lubhu land pooling program, Report 1997, Kathmandu Valley Town Development Committee, Lalitpur committee

[7] Lubhu VDC Profile (2008). Lubhu Village Development Committee, Lalitpur, Nepal.

[8] Pant, M. (2002). A Study on the Spatial Formation of Kathmandu Valley Towns- The case of Thimi. University of Kyoto, Japan.

[9] Pruscha, C. (Ed.). (1975). Kathmandu Valley, the Preservation of Physical Environment and Cultural Heritage A Protective Inventory. Vienna: Anton Schroll $\&$ Co, Publishers.

[10] Settlement Pattern. (2010). Kathmandu Valley Environment Outlook, Chapter 4. Retrieved from ww.rrcap.org/reports/eo/kv/KVEO_4_settle.pdf

[11] Shrestha, O. (1997). Fortified Town Lubhu and Security. Lubhu Mahotsav (Smarika) Lubhu village development committee; Lubhu, Lalitpur Nepal, p.21 